\title{
FLOW UNITS DETERMINATION USING FLOW ZONE INDICATOR FOR CARBONATE RESERVOIR
}

\author{
Abdul Haris ${ }^{1, a)}$, Agus Riyanto ${ }^{1}$, Tri Aji Adi Harsanto², Ambar Rachmanto ${ }^{3}$, and \\ Adang Sukmatiawa ${ }^{3}$ \\ ${ }^{1}$ Geology and Geophysics Program, FMIPA Universitas Indonesia, Kampus UI Depok, Indonesia. \\ ${ }^{2}$ Physics Program, FMIPA, Universitas Indonesia, Kampus UI Depok, Indonesia. \\ ${ }^{3}$ PT Pertamina EP. \\ Email: a)abdharis@sci.ui.ac.id
}

\begin{abstract}
In the last few years, the use of flow unit technique in the oil and gas industry has shown a great deal of success. Porosity and permeability from wire-line log and special core data analysis (SCAL) along with its cementation exponent value were integrated to characterize the reservoir in terms of pore volume caused by facies changing. In this work, we determine flow unit of the carbonate reservoir, which is applied to the Northwest Java Basin Field, Indonesia by performing the flow unit analysis, which allows approximating absolute permeability. Furthermore, the quantity and the flow unit of the reservoir rock is also determined to identify the secondary porosity. To reduce the level of uncertainty, wire-line logs data were validated with core data before it is used to interpret the reservoir. Subsequently, the result can be extrapolated to un-cored wells. Our experiment shows that flow units can be determined reliably from the integration between porosity and permeability, which have defined two different rock types in term of flow unit zone. The correlation of the flow units between wells leads to the definition of reservoir quality.
\end{abstract}

Keywords: reservoir quality, flow unit of reservoir rock, and carbonate reservoir.

\section{INTRODUCTION}

Indonesia North West Java Basin has been known as a major hydrocarbon production in the Java region. This basin is located between the Sunda Shelf in the North, Bogor Trough in the South, Karimun uplift in the East and Seribu Islands in the West [1]. North West Java Basin is affected by the faulting block system trending North-South. This faulting block system has derived horst and graben structures. These faults have divided the basin into several parts of sub-basin, those are Jatibarang, Pasir Putih, Ciputat and Rangkas Bitung subbasin. Moreover, this faulting block system has also caused several basements high such as Arjawinangun, Cilamaya, Pamanukan, KandanghaurWaled, Rengasdengklok, and Tangerang uplift. Based on the stratigraphy and structural patterns, West Java basin has undergone several phases of sedimentation and tectonic settings since the Eocene to the present [2].

One of the main reservoirs in the basin is composed of carbonate rocks. In contrast to the sandstone reservoir, the carbonate reservoirs tend to have high complexity. These differences appear because of some factors like differences in mineral content, the forming process, and the depositional environment. Effects of the complexity of carbonate reservoirs appear on porosity and permeability parameters that tend to be heterogeneous. This led to the exploration and development of carbonate 
reservoirs will have a high level of uncertainty. The ambiguities occur in the determination of some parameters like net-pay, hydrocarbon reserve and productivity level of the [3, 4].

In this study, petrophysical analysis and flow unit mapping have been carried out to improve reservoir characterization quality and reduce the uncertainty in carbonate reservoirs in term of inter wells connectivity based on fluid flow zone description within the reservoir. Petro-physical analysis, which is an evaluation of logging record from the exploration wells to determine the lithology, fluid content and other petrophysical properties at a rock formation by analyzing the physical properties such as clay content, rock porosity, water saturation and permeability, is performed to minimize ambiguities level. The physical properties that had to be analyzed were obtained from petrophysical calculations by using well log data. Core and mud-log data are also used for verification [5]. Flow unit, which is presented by the portion of the total volume of the reservoir, is conducted to identify flowing and non-flowing zone within the reservoir $[6,7]$.

\section{METHODS}

The carbonate is a unique reservoir and the most productive reservoir for oil and gas production. In many cases, the biggest oil and gas production is coming from the limestone reservoir. Many studies of the limestone reservoir rock are still developing until now. The earliest study of carbonate rock was focusing on a static parameter such as porosity, petrographic and depositional texture. But this focus currently is shifting to a dynamic parameter such as permeability and flow unit. The previous study determined the petrophysical properties of carbonate directly by the visual reading of the carbonate sample [8]. The visual reading of carbonate rock sample relies dependent on individual expertise in evaluating the pore space and permeability [6].

Their heterogeneity causes the interesting topic of carbonate reservoir which makes it still developing. The heterogeneity makes exploration and development of carbonate reservoir are so tricky. This condition makes many experts tried to classify and characterize carbonate reservoir, some of them classified the carbonate reservoir into rock quality, flow unit, lito facies, petro facies and electro facies $[9,10]$.

Flow units classification is different with the others. Flow unit is defined as a mapping of the portion from the total volume of the reservoir, where the geological conditions and petrophysical properties of the reservoir affect the fluid flow within the reservoir [8]. According to Ebanks, et al. 1987 Flow unit has several characteristics including:

1. Flow unit occurred in the specific volume of the reservoir which is heterogeneous and saturated by fluid

2. Flow unit is a method that uses correlation and mapping between wells

3. Zonation of the flow units within the reservoir is using wire-line logs were validated by the core data.

4. Flow units within the reservoir are allowing it to interact with other fluid flow.

The first important parameter in defining the flow unit is permeability. Permeability is determined as the rock abilities to pass through the fluid. The unit of Permeability is milli Darcy which is ranging from $0.1 \mathrm{mD}$ to $1000 \mathrm{mD}$. Evaluation of the permeability of each well in this study can be calculated with empirical calculations. The permeability can be determined as a function of the porosity. The core data control permeability and porosity are then followed by calculating the RQI (Rock Quality Index) by the equation 1 .

$$
\text { Rock quality }=0.0034 \sqrt{ } \mathrm{k} / \phi
$$

Where $\mathrm{k}$ and $\phi$ present the permeability and porosity respectfully. The obtained rock quality is then used to generate calculations Flow Zone Indicator (FZI) by using equation 2.

$$
\mathrm{FZI}=\mathrm{RQI} / \phi
$$

Carbonate is very heterogeneous rocks. To classify or distinguish the rock zone, flow unit evaluation performed by using a calculation of FZI and RQI [11, 12]. Flow unit classification based 
FZI and RQI can be carried out simultaneously. The classification, which is determined by FZI has the same gradient, is reflected by the same cluster of the flow unit $[11,13]$.

\section{RESULTS AND DISCUSSION}

In this study, we have characterized carbonate reservoir of Baturaja formation of north-west Java basin. Based on the core sample five well log data. The flow unit zonation is determined by considering the distribution of reservoir petrophysical properties. The shale volume, porosity, water saturation and permeability were calculated for each well based on the available log data. The calculated petrophysical properties were then correlated to the available core sample to estimate the un-cored sections.

\section{Shale Volume}

The shale volume (Vsh) is obtained by calculating the gamma-ray index (IGR), which use several parameters such as GR shale (GRsh), GR sand (GRcln) and neutron porosity shale (NPHIsh). Determination of GR shale (GRsh) and GR sand (GRcln) was performed according to the character of GR curve on each formation. When determining the cut of it must be calibrated using lithology information, which is obtained from the mud-log data. GR index value will be viewed as its correlation with lithological information derived from mud-log. FIGURE 1 is the curve of shale volume that has been calibrated with the mud-log data. GR curve is shown in the second track, which includes baseline parameters of sand and shale. The curve shows different characters of sand and shale baseline for each formation. Vsh calculation results are shown in the fifth track. There are also points of data derived from the mud-log data. The gamma ray index, which is resulted from the calculation, shows a good match with the correlation between $70-90 \%$ with the mud-log data, especially for the targeted Baturaja formation.

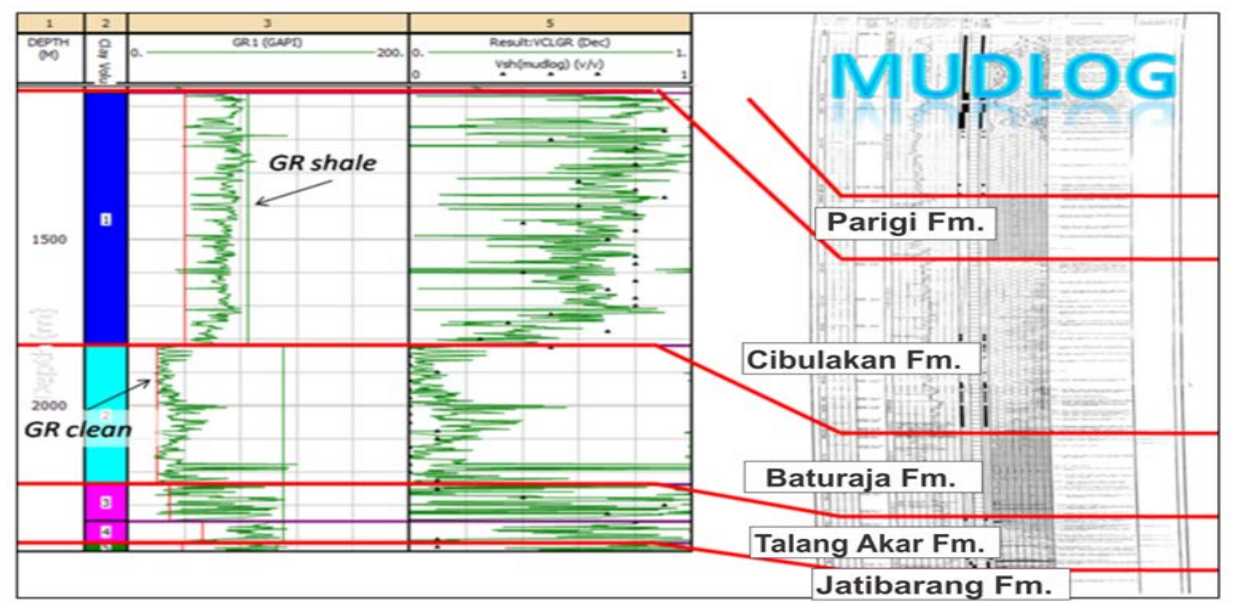

FIGURE 1. Shale volume log, which is integrated with lithological information of mud-log.

\section{Porosity}

Porosity calculation is carried out by using three input parameters those are a sonic log, density $\log$, and neutron log. These three input data are used to generate four types of porosity; those are sonic porosity, density porosity, neutron porosity and neutron-density porosity. To determine the best porosity, all of the four porosity types must be compared to porosity, which is obtained by routine core analysis as shown in FIGURE 2. Based on FIGURE 2 neutron-density porosity is the best porosity type which has high conformity with normal core porosity. 


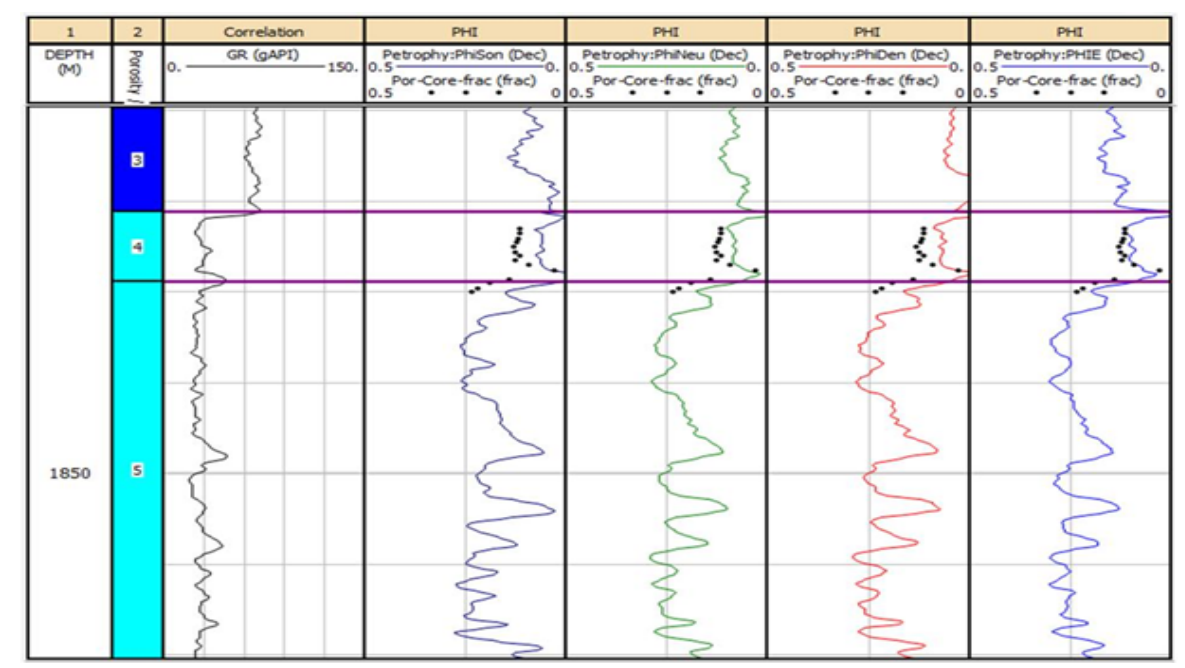

FIGURE 2. Porosity obtained from multiple logs from left to right (sonic, neutron, RHOB, and a combined neutron and RHOB), black color dots indicate porosity values of conventional cores in well-06.

\section{Water Saturation}

Water saturation estimation is carried out using a consolidated sandstones approach for Talangakar formation, consolidated Limestones for Baturaja formation and shaly sandstone for Cibulakan formation. The key parameters for estimating water saturation are $\mathrm{a}, \mathrm{m}$ and $\mathrm{n}$ variables. These parameters at the targeted zone of Baturaja formation were based on SCAL (special core analysis) data from well-06. From SCAL was obtained $m=1,79, n=2.1$ and $a=1$ in the Baturaja Formation. Whereas for the consolidated sandstones model that was used for Talangakar formation obtained $\mathrm{a}=0.81$ and shaly sands for Cibulakan formation $\mathrm{a}=0.81$. A part of the special core analysis report from well-06 is shown in FIGURE 3. The Laboratory test of Special Core Analysis resulted in cementation factor $\mathrm{m}$ and saturation exponent $\mathrm{n}$ as shown in FIGURE 3.

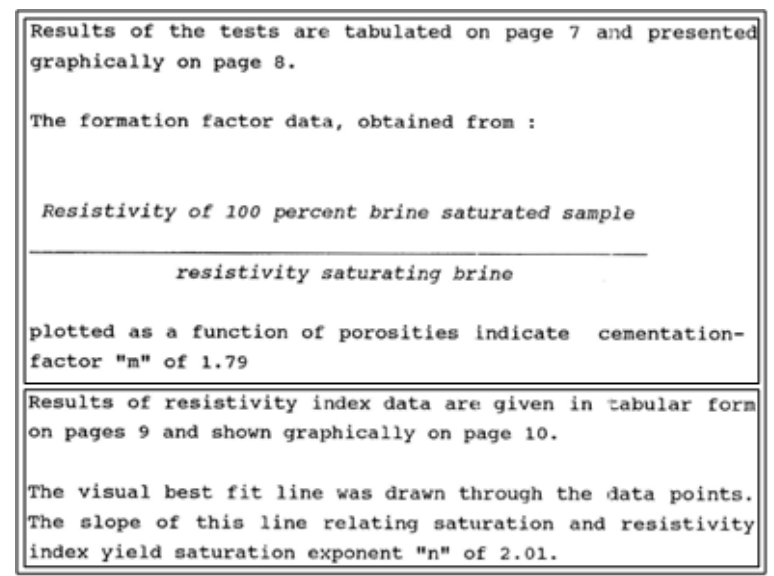

FIGURE 3. SCAL report of the well -06 of Baturaja Formation, which shows that Archie parameter $\mathrm{m}=1.79$ and $\mathrm{n}=2.01$.

The estimated water saturation parameter values also require water resistivity (Rw). This Rw was obtained from formation water analysis. Furthermore, formation water analysis is averaged and used for estimating water saturation. The results of the formation water analysis from individual wells and several formations shown in FIGURE 4. 


\section{Permeability}

Understanding permeability parameter in characterizing reservoir is very important since this parameter plays a significant role in performing production, stimulation, and management. The fact showed that only a few wells were cored due to costs consideration and problems occur during coring. Thereby permeability data is obtained from the integration of well tests, core data analysis, and well logging. This approach is considered to be the lowest cost method. Even it is difficult to predict the permeability of carbonate reservoir.

The permeability calculation is carried out after the effective porosity, and water saturation was obtained. In this study, the equation used to calculate the permeability is approached by the relationship between the porosity and permeability of cores. This equation is used to generate permeability transform for the wells that have no core data and to predict permeability data for each sample depth. The relation between porosity and permeability from core data and its function is shown in FIGURE 5. The validation of predicted permeability is shown in FIGURE 6. All predicted permeability of five wells is shown from left to right track. The excellent correlation between the permeability of core data and the expected permeability is shown in FIGURE 6 on most right track. From this curve, we could say that the predicted permeability is reliable to be used especially in the targeted Baturaja formation. The summary of the reservoir properties (clay content, water saturation, porosity, and permeability) in the targeted composition for each well is shown in Table 1.

Table 1. The average value of clay content, water saturation, porosity and permeability

\begin{tabular}{ccccc}
\hline Well & $\begin{array}{c}\text { Vsh } \\
\mathbf{( \% )}\end{array}$ & $\begin{array}{c}\text { Sw } \\
\mathbf{( \% )}\end{array}$ & $\begin{array}{c}\text { Porosity } \\
\mathbf{( \% )}\end{array}$ & $\begin{array}{c}\text { Permeability } \\
\text { (mD) }\end{array}$ \\
\hline Well_1 & 9.3 & 7.3 & 29.8 & 40.23 \\
Well_3 & 3.62 & 9.49 & 28 & 71.87 \\
Well_4 & 4.53 & 21 & 25.5 & 49.52 \\
Well_5 & 13.6 & 26.2 & 24.9 & 40.41 \\
Well_6 & 19.8 & 20.6 & 13.7 & 50.1
\end{tabular}

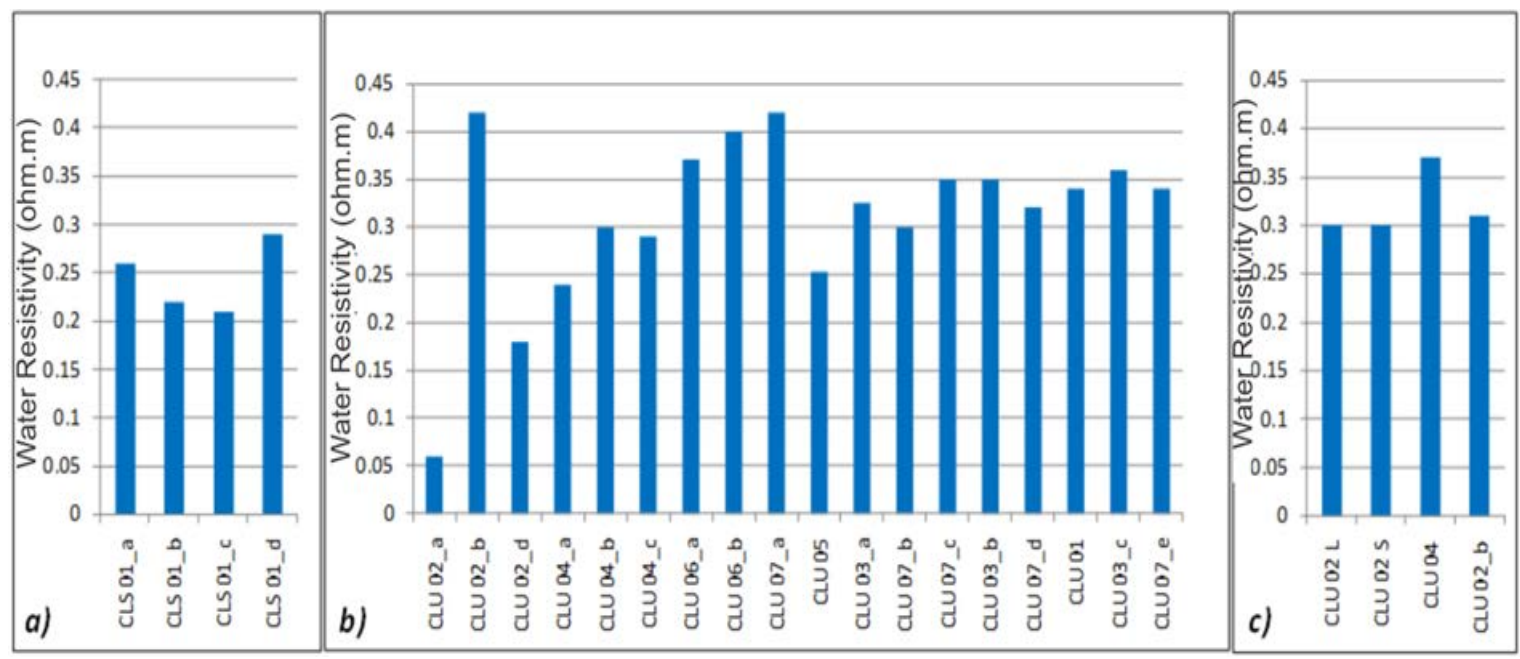

FIGURE 4. Water resistivity for each formation, where the average $R_{w}$ of Cibulakan formation is $=0.245$ a) Baturaja formation is $0.327 \mathrm{~b}$ ) and Talangakar formation is $0.32 \mathrm{c}$ ). 


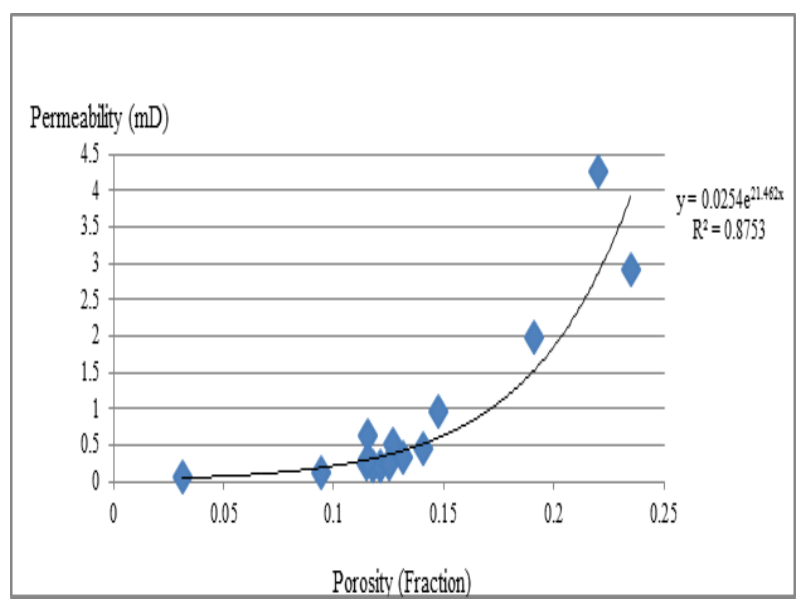

FIGURE 5. Correlation core porosity versus permeability cores
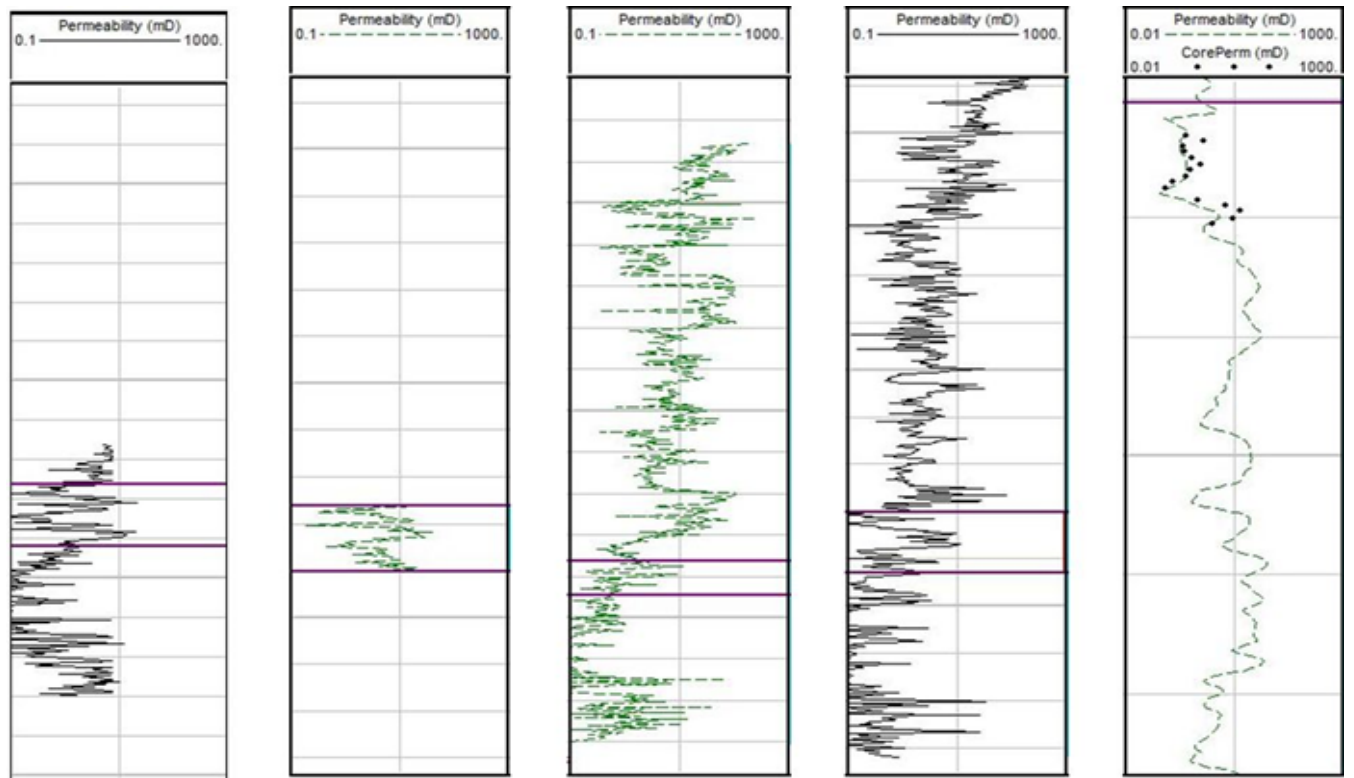

FIGURE 6. Log permeability transforms for Well-01, Well-03, Well_04, Well_05, Well_06 based on equation correlation results permeability core porosity versus permeability cores.

\section{Flow Unit}

The flow unit zonation can be generated using the calculated FZI and RQI. Furthermore, FZI data are sorted from smallest to the largest and then the data are plotted versus sample number to obtain some of the trends, which has the same gradient. The resulted slope is controlled by the result of rock typing and data core. Here is the result of flow unit zonation by using the plot of FZI versus the sample number and also based on the permeability values, which is shown in FIGURE 7.

Refer to the resulted flow unit zonation, and it can be concluded that flow unit zone 1, which is indicated by permeability range of 39.24 up to $84.06 \mathrm{mD}$, can be classified as a flowing zone by means fluids such as hydrocarbons easily traverse this zone. In another hand, flow unit zone 2, which is indicated by permeability range of 14.23 up to $39.24 \mathrm{mD}$, can be classified as a non-flowing zone by means this zone is hard traversing fluids. 


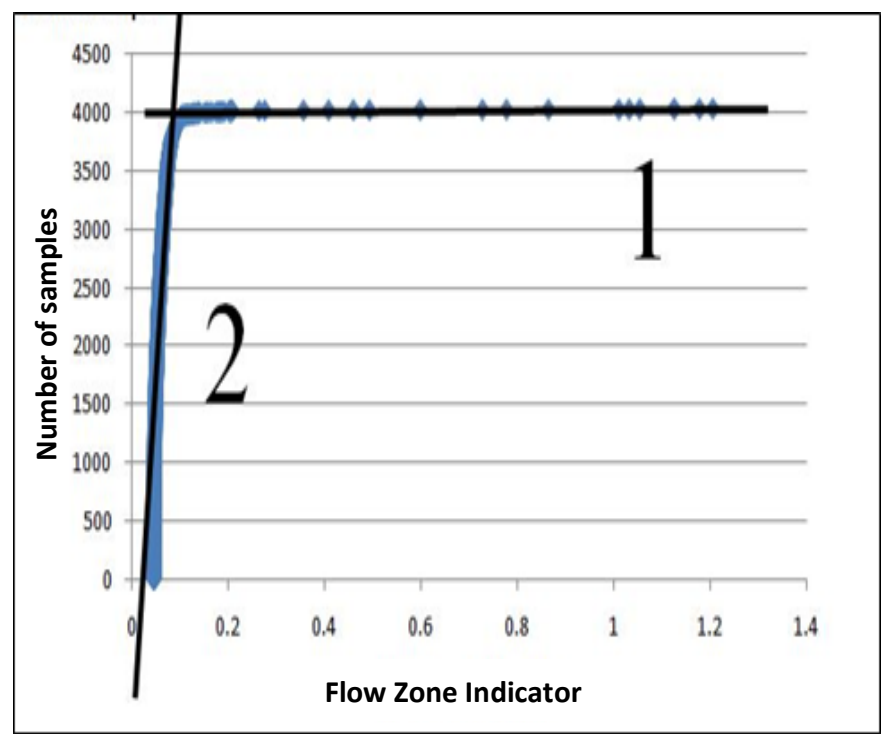

FIGURE 7. The flow unit zonation, which is characterized by two rock types based on the FZI gradient.

\section{CONCLUSIONS}

Reservoir characterization, which is based on well logs are analysis by estimating shale volume, porosity, water saturation and permeability, was successfully carried out to characterize the petrophysical properties and flow capability of the reservoir. The carbonate reservoirs are challenging reservoir because of their close and heterogeneity properties caused by sedimentation process and depositional environment. The close and heterogeneity properties are controlled by varying relationship between porosity and permeability, which was derived from the cross plot of the core sample. The targeted Baturaja formation is classified by two flow unit zonation, where the flow unit zone 1 and 2 are classified as flowing and non-flowing zone respectively.

\section{REFERENCES}

[1] M. A. Jambak, I. Syafri, V. Isnaniawardhani, B. Benyamin, and H. Rodriguez, Facies and Diagenetic Level of the Upper Cibulakan and Parigi Formation, in Randegan and Palimanan Area. Indonesian Journal on Geoscience, (2015). vol. 2, no. 3, pp. 157-166.

[2] R. A. Noble, Petroleum System of Northwest Java Indonesia. In Indonesian Petroleum Association 26th Proceeding, Jakarta, (1997), pp. 585 - 600.

[3] J. Garland, J. Neilson, S. E. Laubach, and K. J. Whidden, Advances in carbonate exploration and reservoir analysis. Geological Society, London, Special Publications, (2012). vol. 370, no. 1, pp. 1-15.

[4] G. M. Hamada, A. A. Almajed, T. M. Okasha, and A. A. Algathe, Uncertainty analysis of Archie's parameters determination techniques in carbonate reservoirs. Journal of Petroleum Exploration and Production Technology, (2013). vol. 3, no. 1, pp. 1-10.

[5] G. B. Asquith, and C. R. Gibson, Basic Well Log analysis for Geologists AAPG Methods in Exploration Series. American Association Petroleum Geologist, (1982). Oklahoma. 216.

[6] W. J. Ebanks Jr, M. H. Scheihing, and C. D. Atkinson, Flow units for reservoir characterization. Development geology reference manual: AAPG Methods in Exploration Series, (1992). vol. 10, pp. 282-285.

[7] A. Mirzaei-Paiaman, H. Saboorian-Jooybari, and P. Pourafshary, Improved method to identify hydraulic flow units for reservoir characterization. Energy Technology, (2015). vol. 3, no. 7, pp. 726-733. 
[8] F. J. Lucia, Petrophysical parameters estimated from visual descriptions of carbonate rocks: a field classification of carbonate pore space. Journal of petroleum technology, (1983). vol. 35, no. 3, pp. 629-637

[9] C. Y. Akbaş, Determination of Flow Units for Carbonate Reservoirs by Petrophysical-Based Methods (Doctoral dissertation, Middle East Technical University), (2005).

[10] J. A. Rushing, K. E. Newsham, and T. A. Blasingame, Rock typing: Keys to understanding productivity in tight gas sands. In SPE Unconventional Reservoirs Conference. Society of Petroleum Engineers, (2008, January).

[11] B. Abrar, F. Wisaksono, and A. Soendaroe, Flow Units Characterization and Application of Matrix Exponential Value ('M-Value') to Identify Secondary Porosity in Carbonates: A Successful Story to Identify By-Passed Oil and Increase Production. In 36th annual Conference Proceedings Indonesian Petroleum Association, (2012).

[12] Z. Riazi, Application of integrated rock typing and flow units identification methods for an Iranian carbonate reservoir. Journal of petroleum science and engineering, (2018). vol. 160, no. 1 , pp. 483-497.

[13] P. J. R. Fitch, Heterogeneity in the petrophysical properties of carbonate reservoirs (Doctoral dissertation, University of Leicester), (2011). 